\section{Foundations of Physics}

By Prof. R. B. Lindsay and Prof. H. Margenau. Pp. xiv +537. (New York : John Wiley and Sons, Inc.; London: Chapman and Hall, Ltd., 1936.) 22s. 6d. net.

THERE is a type of theoretical physics which consists in the mechanical use of mathematical apparatus; it is to be met with at all stages. The intermediate student develops a fatal facility in the handling of $1 / v+1 / u=1 / f$, knowing little and caring less about the physics that is involved. Later, his theoretical physics is summed up in certain differential equations of the second order and, arrived at the boundaries of his subject, we may see him later still employing the most recent technique in matrix theory and in vector algebra, finding in this technique an instrument for saving, rather than for stimulating, thought.

The authors of this most valuable volume by no means despise mathematical aids, but mathematics is always the servant, and there is no danger of losing the physical argument in a maze of mechanically handled mathematical symbols. The book is a real study of the foundations of physics, and whether the authors are engaged in the exposition of the bases of classical mechanics, or in explaining the statistical point of view, the electron theory and special relativity, or the latest developments in quantum mechanics, they are clear, critical and stimulating.

It is not too much to say that the book is one of the best attempts that have yet been made to survey the foundations of modern physics in a manner at once thorough and yet not over-detailed. It may be unreservedly commended to the notice of students in the honours schools of physical science. A. F.

\section{Logic in Theory and Practice}

By Prof. C. G. Shaw. Pp. xvii +428. (London : Sir Isaac Pitman and Sons, Ltd., 1935.) 8s. 6d. net.

Av additional text-book of logic will not necessarily improve the "low ranking in popularity" of that subject. Yet, Prof. Shaw has written one with the object of trying to make logic "as vital and interesting as its frigid forms will permit". It is difficult to say whether the author has succeeded in this undertaking, as the response has to come from the student rather than from the teacher. But in so far as the latter is concerned, he will find little in this new book to justify its substitution for other similar works. A point in its favour is the fact that the author tries to be more human in his exposition of the traditional theories : his treatment of the logic of judgment and of the hypothetical syllogism are good illustrations of this characteristic. But on the other hand, there are many points of scientific method which he has deliberately overlooked, though they have their place in the scheme of the inductive process. The additional chapters of the theory of knowledge are not at all out of process, though they raise more problems than they can attempt to solve. The writing and the production of the book show, nevertheless, that logic still has a good following and that it deserves a still greater one.
Das Grosse Moos im westschweizerischen Seelande und die Geschichte seiner Entstehung

Von Werner Lüdi. (Veröffentlichungen des Geobotanischen Institutes Rübel in Zürich, Heft 11.) Pp. $344+13$ plates. (Bern : Hans Huber, 1935.) 19.80 francs.

"DAs Grosse Moos" is the name of the extensive plain lying between the lakes of Neuenburg (Neuchâtel), Bieler (Bienne) and Murten (Morat) in western Switzerland at the foot of the Jura range. The area has been subjected to considerable floodings, to remedy which artificial drainage on a considerable scale has been undertaken and has led to the lowering of the water-level in all the lakes and an increase in cultivated land. The volume under notice includes a very full account of the existing ecology and of the history of the area.

By a combination of methods, it is shown that there have been considerable fluctuations in waterlevel in the lakes, and the surrounding area, during post-glacial times. These fluctuations have been mapped mainly by the construction of pollendiagrams, based on the examination of samples from the peat deposits, and on the correlation of the variations in pollen content with archæological and geological evidence and comparison with similar results obtained in other parts of Europe.

The work is essentially a very careful and detailed account of the influence of post-glacial climatic changes, working especially through erosion, and of man, on the topography and vegetation of a limited area in Central Europe. As such it is a valuable contribution to the accumulating knowledge of the history of European plant-life.

W. B. T.

\section{A Documentary History of Primitivism and Related} Ideas

Vol. 1 : Primitivism and Related Ideas in Antiquity. By Arthur O. Lovejoy and George Boas: with Supplementary Essays by W. F. Albright and P. E. Dumont. Pp. $x v+482$. (Baltimore: The Johns Hopkins Press ; London: Oxford University Press, 1935.) 22s. 6d. net.

THIS imposing undertaking, of which the first volume is under review, proposes to give direct evidence of the views held throughout Western civilization on primitivism and related ideas. Its chief interest lies in the compilation and classification of the various quotations selected by the authors; so that it is really with a source book about the conceptions of Nature as shown through the ages that we are concerned. This first volume deals with the Greek and Roman authors, of which it gives several and large extracts. Though there is little to say about the extracts themselves, it may be pointed out that half of the labour done is of little value, for each extract is followed by a translation. The latter alone would have been sufficient.

The publication of the book, which is bound to have a limited appeal, is, however, symptomatic. For it gives an encouraging background to the advanced views about the individual and society, which are held and defended in some quarters. 